O B E EDUCATION Tersedia online:http://journal.iainkudus.ac.id/index.php/jbe

\title{
Discovery dan Pendekatan Jelajah Alam Sekitar (JAS) pada Pembelajaran Konsep Klasifikasi Makhluk Hidup
}

\author{
Mansur $S^{1}$, Andre Pratama F Xaverius ${ }^{2}$ \\ ${ }^{1,2}$ Pendidikan Biologi, Universitas Nusa Nipa Nusa Tenggara Timur Indonesia \\ Email: mansursaputra00@gmail.com
}

\begin{abstract}
ABSTRAK
Penelitian ini bertujuan untuk mengetahui pengaruh pendekatan Jelajah Alam Sekitar (JAS) terhadap keaktifan dan hasil belajar peserta didik kelas VII SMP Muhammadiyah Waipare pada konsep klasifikasi makhluk hidup. Metode yang digunakan adalah quasi exsperimental design dengan desain nonequivalent control grub design. S Sampel pada penelitian ini adalah kelas VII C berjumlah 21 siswa sebagai kelas eksperimen dan kelas VII D berjumlah 20 siswa sebagai kelas kontrol. Teknik penentuan sampel menggunakan sampling purposive. Hasil analisis uji coba instrumen menunjukkan bahwa semua instrumen layak untuk di gunakan. Teknik analisis data meliputi uji normalitas, uji homogenitas dan uji hipotesis. Hasil uji normalitas menunjukkan bahwa sebaran variabel hasil belajar tergolong normal dan hasil uji homogenitas menunjukkan bahwa varians data penelitian homogen. Hasil penelitian menunjukkan bahwa peserta didik sangat aktif mengikuti pembelajaran dengan menggunakan model pembelajaran Jelajah Alam Sekitar (JAS) pada konsep klasifikasi makhluk hidup. Hal ini ditunjukkan oleh hasil analisis keaktifan peserta didik sebesar 81,77. Selain itu, terdapat pengaruh yang signifikan antara model pembelajaran jelajah alam sekitar (JAS) terhadap hasil Belajar kelas VII SMP Muhammadiyah Waipare pada konsep klasifikasi makhluk hidup. Hal ini di tunjukkan oleh analisis uji t diperoleh nilai signifikansi $<0,05$ yaitu $(0,000<0,05)$.
\end{abstract}

Kata Kunci : Jelajah Alam Sekitar (JAS), keaktifan, hasil belajar

\section{ABSTRACT}

This study aims to determine the effect of the Approach of Natural Surrounding Approaches (JAS) on the Activities and Learning Outcomes of Grade VII Students of Muhammadiyah Middle School Waipare on the concept of Classification of Living Things. The method used is a quasi experimental design with the Nonequivalent control grub design. The population in this study were all grade VII students of Muhammadiyah Waipare Middle School. The sample in this study was class VII C totaling 21 students as the experimental class and class VII D totaling 20 students as the control class. The technique of determining the sample using purposive sampling. Analysis of the instrument trials include validity test, reliability test, difficulty level, differentiation test. The results of the analysis of the instrument trials indicate that all instruments are suitable for use. Data analysis techniques include normality test, homogeneity test and hypothesis test. The normality test results show that the distribution of learning outcomes variables is normal and the homogeneity test results indicate that the research data variance is homogeneous. The results of the study showed that students were very active in following the learning by using the JAS model of the Living Classification concept. This is shown by the analysis of student activity of 81.77. There is a significant influence on the model of Surrounding 
Nature Exploration (JAS), on the learning outcomes of Grade VII Muhammadiyah Waipare Middle School on the concept of Classification of Living Things. This is indicated by the test analysis obtained significance value $<0.05$, i.e. $(0,000<0.05)$.

Keywords: Exploration of Surrounding Nature (JAS), Activeness, Learning Achievement

\section{PENDAHULUAN}

Pendidikan merupakan usaha sadar dan terencana untuk mewujudkan suasana belajar dan proses pembelajaran agar peserta didik secara aktif mengembangkan potensi dirinya. Pendidikan memiliki peranan yang penting untuk meningkatkan mutu sumber daya manusia (SDM) dalam kehidupan. Sistem pendidikan nasional menjelaskan bahwa pendidikan berfungsi mengembangkan watak dan peradaban bangsa. Pendidikan juga bertujuan untuk mencerdaskan kehidupan bangsa agar anak bangsa menjadi beriman dan bertaqwa kepada Tuhan Yang Maha Esa, cerdas, terampil, kreatif, inovatif, bertanggung jawab terhadap bangsa dan negara serta menjadi warga negara yang demokratis (Departemen Pendidikan Nasional, 2003).

Salah satu masalah yang dihadapi dunia pendidikan adalah masalah lemahnya proses pembelajaran. Proses pembelajaran di dalam kelas diarahkan kepada kemampuan peserta didik untuk menghafal informasi. Proses belajar terjadi karena peserta didik mempelajari sesuatu yang ada di lingkungan sekitar dan tidak sekadar menghafal informasi tanpa memahaminya (Sanjaya, 2014). Seiring dengan berkembangnya ilmu pengetahuan dan teknologi, proses pembelajaran juga mengalami perubahan. Sebagai akibat dari perubahan tersebut banyak permasalahan yang muncul dalam proses pembelajaran dapat dipecahkan dengan upaya penguasaan dan peningkatan ilmu pengetahuan dan teknologi (Slavin, 2011). Meskipun banyak pula masalah pembelajaran khususnya dalam pemahaman konsep yang dapat diselesaikan secara kontekstual dari pengalaman hidup peserta didik setiap hari, salah satunya pemahaman konsep dalam IPA.

Hakikat belajar IPA adalah mempelajari alam sekitar dengan cara-cara ilmiah. Untuk itu peserta didik perlu diberikan pengalaman belajar yang dapat mengembangkan kemampuan berpikir, keterampilan proses dan sikap ilmiah. Hal ini sesuai dengan tuntutan standar isi mata pelajaran sains di SMP. Peran pertanyaan dan strategi berpikir sangat penting untuk pemberdayaan berpikir peserta didik. Pembelajaran IPA di SMP merupakan proses belajar yang menyangkut hubungan antara makhluk hidup dengan lingkungannya. Suatu proses belajar yang berhubungan aktivitas dunia nyata sehingga terjadinya interaksi antara peserta didik dengan peserta didik, peserta didik dengan guru, dan peserta didik dengan lingkungannya. Alasan inilah 
yang menjadi alasan bahwa semua harus kembali pada hakekat sains yaitu sebagai suatu proses penelusuran. Oleh karena itu, peserta didik hendaknya juga diajak untuk ikut terlibat dalam proses penelusuran dari suatu penemuan misalnya melalui penelusuran di alam. Kelebihan pembelajaran memanfaatkan alam, yaitu peserta didik dapat mengembangkan pengetahuan dan guru dapat melakukan proses belajar yang tidak kalah efektif dengan proses belajar yang dilakukan dalam kelas (Winataputra, 2005). Pakar pendidikan menyebutkan bahwa pendidik maupun peserta didik adalah subyek pendidikan, karena keduanya dianggap mempunyai karakter yang berperan penting dalam proses pendidikan.

Salah satu tujuan pembelajaran IPA terutama biologi di SMP adalah meningkatkan kesadaran akan pelestarian lingkungan. Pembelajaran biologi merupakan bagian dari pendidikan lingkungan, yang memiliki nilai strategis dalam menanamkan pengetahuan yang berkaitan dengan masalah-masalah lingkungan. Sesuai dengan kurikulum 2013 guru harus melibatkan partisipasi aktif dari peserta didiknya, dapat memanfaatkan penggunaan teknologi, dan dapat mengintegrasikan dengan pengetahuan-pengetahuan lokal. Sehingga dapat mengembangkan semua potensi yang ada di dalam diri peserta didik, baik aspek kognitif, afektif, maupun psikomotorik (Rusman, 2013). Salah satu pendekatan yang dapat digunakan untuk mencapai tujuan tersebut adalah melalui pendekatan Jelajah Alam Sekitar (JAS) (Sitiatava, 2013).

Pendekatan Jelajah Alam Sekitar (JAS) tidak mengharuskan peserta didik menghafal informasi, tetapi mendorong peserta didik untuk mengembangkan informasi pengetahuan yang diperoleh berdasarkan konsep biologi melalui proses eksplorasi dan investigasi (Yuniastuti, 2013). Hal tersebut menjadikan penerapan pendekatan JAS dapat dijadikan sebagai alternatif dalam memperbaiki proses pembelajaran. Proses pembelajaran IPA (sains) menekankan pada pemberian pengalaman langsung untuk mengembangkan kompetensi agar menjelajahi dan memahami alam sekitar secara ilmiah (Sudarmin \& Widiyatmoko, 2012). Pendekatan JAS sebagai strategi pembelajaran yang melibatkan unsur ilmu atau sains, proses penemuan ilmu (inkuiri), keterampilan berkarya, kerjasama, permainan yang mendidik, kompetisi, tantangan dan sportivitas (Mulyani et al., 2008).

Pendekatan JAS menekankan pada kegiatan pembelajaran yang dikaitkan dengan situasi dunia nyata, sehingga selain dapat membuka wawasan berpikir yang beragam dari seluruh peserta didik. Pendekatan ini memungkinkan peserta didik dapat mempelajari berbagai konsep dan cara mengaitkannya dengan dunia nyata sehingga hasil belajarnya lebih berdaya guna (Suriasumantri, 
1998). Pendekatan JAS memanfaatkan lingkungan alam sekitar peserta didik baik lingkungan fisik, sosial, maupun budaya sebagai obyek belajar biologi yang fenomenanya dipelajari melalui kerja ilmiah (Negara, Ifrianti, \& Kuswanto, 2012). Tujuan pembelajaran JAS adalah untuk menggali, membangun, melatih, dan membiasakan kemampuan personal, sosial, berpikir rasional, metakognisi, dan kognisi. Dalam proses pembelajaran biologi yang berorientasi pada pencapaian kompetensi pembelajaran sains antara lain penguasaan terhadap pengetahuan ilmiah, sikap ilmiah, dan keterampilan ilmiah melalui fase utama JAS yang terdiri dari eksplorasi, interaksi, komunikasi, refleksi, dan evaluasi (Alimah, 2012).

Hasil observasi yang dilakukan pada bulan Maret 2019 di SMP Muhammadiyah Waipare bahwa guru belum maksimal menggunakan metode dan model pembelajaran yang bervariasi sehingga peserta didik kurang aktif pada saat proses pembelajaran. Pembelajaran dengan memanfaatkan alam sebagai media belajar kurang diterapkan dalam pembelajaran IPA dan model yang digunakan adalah discovery learning dan saintifik. Padahal jika dilihat dari lingkungan sekitar sekolah terdapat berbagai macam tumbuh-tumbuhan yang hidup dan ini dapat dijadikan sebagai media belajar bagi peserta didik.

Beberapa penelitian terdahulu dijelaskan kelebihan pemanfaatan lingkungan sekitar sebagai media belajar antara lain Azhar (2015) menyatakan bahwa pendekatan JAS dalam proses pembelajaran biologi berpengaruh terhadap peningkatan hasil belajar peserta didik. Sedangkan Hidayah (2014) memperoleh hasil bahwa penerapan pendekatan JAS dapat meningkatkan keaktifan dan hasil belajar biologi peserta didik. Syaufidin (2013) menjelaskan pendekatan JAS terbukti efektif ditinjau dari hasil belajar peserta didik dari pada ceramah. Kegiatan pembelajaran dengan menggunakan JAS dapat meningkatkan keaktifan dan dan hasil belajar. Diperkuat dengan penelitian Mansur (2018) pendekatan JAS berpengaruh terhadap hasil belajar biologi peserta didik kelas VII SMPK Bina Wirawan Maumere tahun pelajaran 2016/2017 pada materi pokok klasifikasi mahluk hidup dengan menunjukkan perbedaan yang sangat signifikan antara kelas eksperimen yang menggunakan pendekatan JAS lebih tinggi dari pada kelas kontrol yang menggunakan metode konvensional.

\section{METODE PENELITIAN}

Penelitian ini menggunakan pendekatan jelajah alam sekitar (JAS) untuk mengukur keaktifan dan hasil belajar peserta didik. Penelitian ini termasuk penelitian eksperimen, yang 
menggunakan nonequivalent control group desain. nonequivalen control group desain yaitu desain yang hanya menggunakan kelompok eksperimen maupun kelompok kontrol tidak dipilih secara random. nonequivalen control group desain digunakan dalam penelitian ini karena untuk menentukan kelompok eksperimen yang hendak diteliti seperti pada Tabel 1.

Tabel 1. Desain penelitian dengan Nonequivalent Control Group Desain

\begin{tabular}{cccc}
\hline Kelas & Pretest & Treatment & Post Test \\
\hline Eksperimen & $\mathrm{O}_{1}$ & $\mathrm{X}$ & $\mathrm{O}_{3}$ \\
\hline Kontrol & $\mathrm{O}_{2}$ & - & $\mathrm{O}_{4}$ \\
\hline
\end{tabular}

Populasi pada penelitian ini adalah kelas VII yang berjumlah empat kelas. Sampel adalah bagian dari jumlah dan karekteristik yang dimiliki oleh populasi tersebut. Bila populasi besar, dan peneliti tidak mungkin mempelajari semua yang ada pada populasi, misalnya karena keterbatasan dana, tenaga dan waktu, maka peneliti dapat menggunakan sampel yang diambil dari populasi itu (Sugiyono, 2012). Dari empat kelas diambil dua kelas sebagai sampel penelitian yaitu kelas VIIC dan VIID.

Teknik pengumpulan data yang digunakan pada penelitian ini adalah tes dan observasi. Tes dilakukan pada kelas eksperimen dan kontrol pada sebelum dan sesudah dilakukan proses pemebalajaran. Sedangkan lembar observasi yang digunakan berisikan semua aspek keterampilan proses sains yang akan diamati yaitu observasi, klasifikasi, komunikasi, dan mengajukan pertanyaan. Teknik analisis yang dilakukan pada penelitian ini adalah uji normalitas, homogenitas dan uji hipotesis.

\section{HASIL DAN PEMBAHASAN}

Penilaian keaktifan peserta didik dilakukan setiap kegiatan pembelajaran pada kelas eksperimen dan kontrol. 


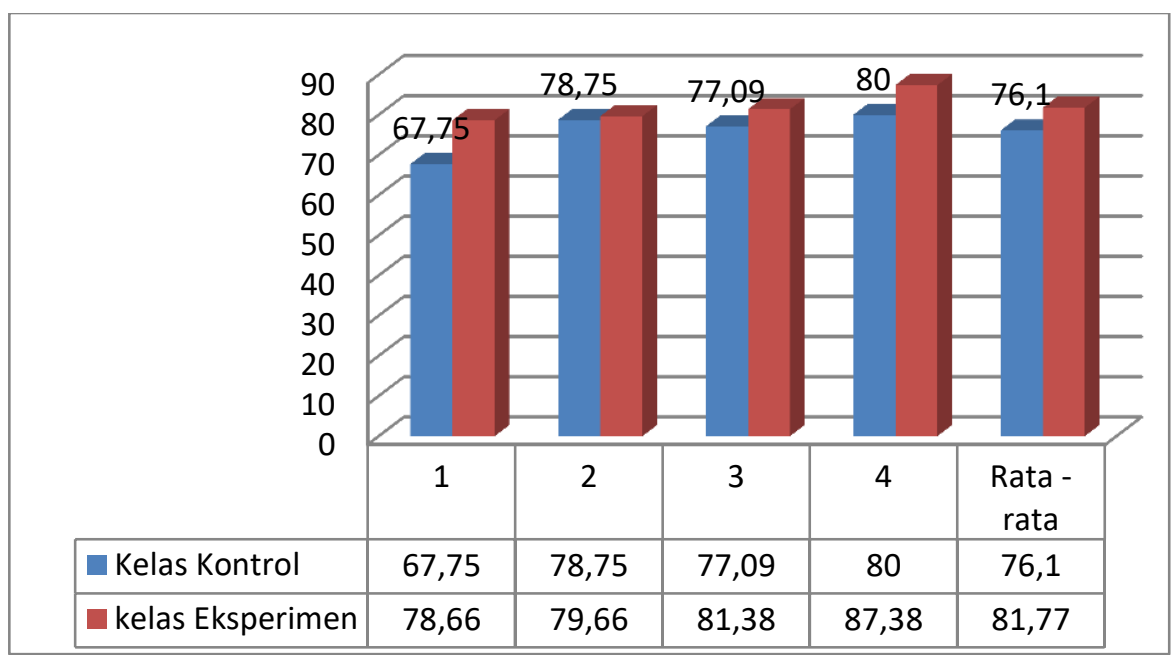

Gambar 1. Rata - Rata Keaktifan Belajar Peserta didik

Tabel 2. Hasil belajar Kognitif Peserta didik kelas Eksperimen dan Kelas Kontrol

\begin{tabular}{ccccc}
\hline & \multicolumn{2}{c}{ VII C Eksperimen } & \multicolumn{2}{c}{ VII D Kontrol } \\
\cline { 2 - 5 } & Pre test & Post test & Pre test & Post test \\
\hline Jumlah Peserta didik & \multicolumn{2}{c}{21} & \multicolumn{2}{c}{20} \\
\hline Rata - rata & \multicolumn{2}{c}{53,57} & \multicolumn{2}{c}{70,04} \\
\hline Nilai Maksimum & 67 & 85 & 40,65 & 54,09 \\
\hline Nilai minimum & 40 & 55 & 60 & 70 \\
\hline
\end{tabular}

Model pembelajaran yang diterapkan pada kelas kontrol adalah model pembelajaran discovery learning dan ditemukan bahwa pada proses pembelajaran pertemuan 1-4 peserta didik kurang berpartisipasi aktif. Pembelajaran discovery lebih menekankan pada ditemukannya konsep atau prinsip yang sebelumnya tidak diketahui. Prinsip belajar yang tampak jelas dalam discovery adalah materi atau bahan pelajaran yang akan disampaikan tidak disampaikan dalam bentuk final akan tetapi peserta didik didorong untuk mengidentifikasi yang ingin diketahui dilanjutkan dengan mencari informasi sendiri kemudian mengorganisasi atau membentuk (konstruktif) yang diketahui dan dipahami dalam suatu bentuk akhir (Kemendikbud, 2013).

Model pembelajaran yang diterapkan pada kelas eksperimen adalah model pembelajaran Pendekatan JAS. Ketika proses pembelajaran pertemuan 1 sampai dengan pertemuan 4 peserta didik sangat berpartisipasi aktif dalam menemukan masalah dalam kehidupan nyata sehari-hari, memecahkan masalah sesuai dengan LKS kemudian melakukan demostrasi di depan kelas. Proses pembelajaran JAS mangajak peserta didik untuk selalu berpartisipasi aktif dalam pembelajaran sesuai dengan langkah-langkah pembelajaran JAS. 
Sudjana (2004) menyatakan bahwa keaktifan peserta didik dapat dilihat ketika peserta didik berperan dalam pembelajaran seperti aktif bertannya kepada peserta didik maupun guru, berdiskusi kelompok dengan peserta didik lain, mampu menemukan dan memecahkan masalah tersebut dan dapat menerapkan yang telah diperoleh untuk menyelesaikan persoalan yang dihadapinya. Sholikah (2014) menjelaskan bahwa keaktifan peserta didik dapat diukur apabila peserta didik ikut berpartisipasi dalam menentukan tujuan pembelajaran, sehingga peserta didik mengetahui apa tujuan yang akan dicapai saat pembelajaran tersebut. Berdasarkan pemaparan pendapat tersebut dapat disimpulkan bahwa proses pemebelajaran dapat berjalan dengan baik apabila keaktifan peserta didik dalam pembelajaran dapat memenuhi beberapa kriteria tersebut. Melalui pendekatan JAS peserta didik didorong untuk mengumpulkan informasi-informasi yang berkaitan dengan materi klasifikasi makhluk hidup.

Sudjana (2004) menyatakan keaktifan peserta didik dapat dilihat dalam hal: (1) turut serta dalam melaksanakan tugas belajarnya; (2) terlibat dalam pemecahan masalah; (3) bertanya kepada peserta didik lain atau guru apabila tidak memahami persoalan yang dihadapinya; (4) berusaha mencari berbagai informasi yang diperlukan untuk pemecahan masalah;(5) melaksanakan diskusi kelompok sesuai dengan petunjuk guru;(6) menilai kemampuan dirinya dan hasil-hasil yang diperolehnya; (7) melatih diri dalam memecahkan soal atau masalah yang sejenis; (8) kesempatan menggunakan atau menerapkan apa yang diperoleh dalam menyelesaikan tugas atau persoalan yang dihadapinya. Berdasarkan uraian di atas dapat disimpulkan keaktifan peserta didik dapat dilihat dari berbagai hal seperti memperhatikan (visual activities), mendengarkan, berdiskusi, kesiapan peserta didik, bertanya, keberanian peserta didik mendengarkan, memecahkan soal (mental activities)

Keaktifan guru juga sangat diperlukan dalam proses pembelajaran salah satu peran guru yaitu sebagai perencana pengajar (Slameto, 2010). Guru harus memiliki kemampuan dan pengetahuan yang cukup tentang prinsip belajar dan bagaimana merancang kegiatan belajar mengajar seperti merumuskan tujuan, memilih bahan, memilih model pembelajaran, menetapkan evaluasi dan sebagainya. Guru juga harus mampu memberikan penilaian hasil belajar, sehingga dalam proses pembelajaran guru tidak hanya menyampaikan materi tetapi memantau setiap perkembangan peserta didik.

Dari hasil penelitian diperoleh bahwa hasil pre-test dan posttest pada kelas VII (kelas eksperimen) di peroleh nilai rata - rata pretest $=53$ dan posttest $=70$ sedangkan kelas kontrol) di 
peroleh nilai rata - rata pretest $=40$ dan posttest $=54$. Pretest diberikan pada awal kegiatan pembelajaran pada kelas kontrol dan kelas ekperimen dengan jumlah 15 butir soal. Rata-rata nilai pretest kelas eksperimen dengan nilai maksimum 67 dengan nilai minimum 40 sedangkan rata-rata dari nilai kelas kontrol 60 dengan nilai maksimum sebesar 60 dan nilai minimum 20.

Post-test dilaksanakan pada akhir pembelajaran setelah diberikan perlakuan pada kelas eksperimen dengan model pembelajaran jelajah alam sekitar dan kelas kontrol dengan menggunakan model discoveri learning. Nilai rata-rata pada kelas eksperimen sebesar 83 dengan nilai maksimum sebesar 80 dan nilai minimum sebesar 70, sedangkan nilai rata-rata pada kelas kontrol sebesar 72,2 dengan nilai maksismum sebesar 80 dan nilai minimum sebesar 50. Ratarata nilai peserta didik menunjukkan hasil belajar peserta didik pada kelas eksperimen lebih tinggi dibandingkan dengan hasil belajar peserta didik kelas kontrol. Hal ini di sebabkan karena kelas eksperimen diberi perlakuan yaitu menggunakan model pemebelajaran JAS sedangkan pada kelas kontrol diberikan perlakuan dengan model pembelajaran Discoveri learning.

Perbedaan nilai rata-rata posttest yang didapatkan pada kelas eksperimen dan kelas kontrol di karenakan kelompok peserta didik pada kelas eksperimen yang menggunakan model pembelajaran JAS lebih cenderung lebih aktif dalam kegiatan pembelajaran. Peserta didik pada kelas eksperimen tidak hanya dituntut untuk menguasai materi tetapi bagamana mereka dapat menggunakan potensi yang dimiliki untuk mengembangkan kemampuan berpikirnya secara optimal. Kelompok peserta didik pada kelas kontrol yang menggunakan model pembelajaran discoveri learning terkesan bersifat pasif dan kurang terlibat aktif karena terpaku pada penjelasan guru mengenai materi yang di ajarkan, ditemukannya konsep atau prinsip yang sebelumnya tidak diketahui.

Prinsip belajar yang nampak jelas dalam discovery adalah materi atau bahan pelajaran yang akan disampaikan tidak disampaikan dalam bentuk final akan tetapi peserta didik didorong untuk mengidentifikasi apa yang ingin diketahui dilanjutkan dengan mencari informasi sendiri kemudian mengorganisasi atau membentuk (konstruktif) apa yang mereka ketahui dan mereka pahami dalam suatu bentuk akhir (Kemendikbud, 2013). Belajar penemuan atau discovery merupakan suatu pembelajaran yang melibatkan peserta didik dalam pemecahan masalah untuk pengembangan pengetahuan dan ketrampilan (Istiana, 2015). Melalui penemuan, peserta didik belajar secara intensif dengan mengikuti metode investigasi ilmiah di bawah supervisi guru. Jadi belajar dirancang, disupervisi, diikuti metode investigasi. Tiga ciri utama dari belajar menemukan 
(discovery) yaitu: mengeksplorasi dan memecahkan masalah untuk menciptakan, menggabungkan dan menggeneralisasikan pengetahuan; berpusat pada peserta didik; dan kegiatan untuk menggabungkan pengetahuan baru dan pengetahuan yang sudah ada.

\section{SIMPULAN}

Pendekatan JAS meningkatkan keaktifan belajar peserta didik kelas VII SMP Muhammadiyah Waipare pada konsep Klasifikasi Makhluk Hidup. Hal ini ditunjukkan dengan rata-rata presentase keaktifan belajar peserta didik menggunakan model pembelajaran JAS pada kelas eksperimen lebih besar yaitu $81,77 \%$, sedangkan rata-rata presentase keaktifan belajar peserta didik yang menggunakan model pembelajaran discoveri learning pada kelas kontrol lebih rendah yaitu $76,10 \%$. Pendekatan JAS berpengaruh terhadap hasil belajar kognitif peserta didik kelas VII SMP Muhammadiyah Waipare pada konsep klasifikasi makhluk hidup. Hal ini dapat dilihat pada nilai rata-rata kelas eksperimen lebih tinggi dibandingkan nilai rata-rata kelas kontrol yaitu 74 untuk kelas eksperimen dan 54 untuk kelas kontrol.

\section{DAFTAR PUSTAKA}

Alimah, S. (2012). Pengembangan Pembelajaran Eksperimental jelajah Alam Sekitar pada Mata Kuliah Biologi. Seminar Nasional IPA UNNES. Semarang: Universitas Negeri Semarang.

Departemen Pendidikan Nasional. Undang-Undang Sistem Pendidikan Nasional. , Pub. L. No. 20 (2003).

K, A. (2015). Peningkatan Hasil Belajar dengan Pendekatan Jelajah Alam Sekitar (JAS) pada Materi keanekaragaman Hayati di MTs Miftahul huda sarang Rembang Kelas VII semester Genap. Universitas Islam Negeri Walisongo Semarang.

Mansur, S. (2018). Pengaruh Pendekatan Jelajah Alam Sekitar (JAS) Terhadap Hasil Belajar Peserta didik Pada Materi Klasifikasi Mahluk Hidup di SMPK Binawirawan Maumere. Bioeduscience, 2(1), 74-80. https://doi.org/10.29405/j.bes/74-80121314

Mulyani, S., Marianti, A., Kartijono, N. E., Widianti, T., Saptono, S., Pukan, K. K., \& Bintari, H. (2008). Jelajah Alam Sekitar (JAS) Pendekatan Pembelajaran Biologi. Semarang: Jurusan Biologi Universitas Negeri Semarang.

Negara, H. T. P., Ifrianti, S., \& Kuswanto, E. (2012). Pendekatan Jelajah Alam Sekitar (JAS) dalam meningkatkan kualitas hasil belajar Peserta Didik Pada Materi Penggelolaan Lingkungan. In Prosiding Seminar Nasioanal Sains MIPA dan Aplikasi, 33-40.

Sanjaya, W. (2014). Strategi Pembelajaran Berorientasi Standar Proses Pendidikan. Jakarta: Kencana Prenada Media Grup. 
Sitiatava, R. (2013). Desain Belajar Mengajar Kreatif Berbasis Sains. Yogyakarta: Diva Press. Slameto. (2010). Belajar dan Faktor - Faktor yang Memengaruhinya. Jakarta: Rineka Cipta.

Slavin, R. E. (2011). Cooperatif Learning Teori, Riset dan Praktik. (N. Yusron, Penerj.). Nusa Media.

Sudarmin, \& Widiyatmoko, A. (2012). Pengembangan Modul Pembelajaran Konservasi Mata Pelajaran IPA untuk Menumbuhkan Karaktek Peserta didik yang Cinta Alam. Prosiding Seminar Nasional MIPA UNNES. Semarang: Universitas Negeri Semarang.

Sudjana, N. (2004). Dasar-Dasar Proses Belajar Mengajar. Bandung: Sinar Baru Algessindo.

Sugiyono. (2012). Metode Penelitian Kuantitatif dan Kualitatif dan $R \&$ D. Bandung: Alfabeta.

Suriasumantri, J. S. (1998). Filsafat Ilmu Sebuah Pengantar Populer. Jakarta: Sinar Harapan. 